\section{Kastamonu Eğitim Dergisi Kastamonu Education Journal}

Mayıs 2019 Cilt:27 Sayı:3

kefdergi.kastamonu.edu.tr
Başvuru Tarihi/Received: 13.05 .2018

Kabul Tarihi/Accepted: 23.07.2018

DOI: $10.24106 /$ kefdergi.3061

\title{
Normal Gelişim Gösteren ve Üstün Yetenekli Ortaokul Öğrencilerinin Fen Bilimleri Özyeterlikleri ve Özyeterliklerine Cinsiyetin Etkisi ${ }^{1}$
}

\section{Gender Effect on Self Efficacy and Science Self Efficacy of Gifted and Nongifted Middle School Students}

\section{Özet}

\author{
Kübra Şengül YILDIRIM², Sibel SARAÇOĞLU³
}

Araştırmanın amacı; normal gelişim gösteren ve üstün yeenekli ortaokul öğrencilerinin fen bilimleri özyeterliklerini ve özyeterliklerine cinsiyetin etkisini incelemektir. tespit etmektir. Araştırma 2016-2017 eğitim öğretim yllında Kayseri ili Melikgazi ilçesinde yapıımıştr. Çalışma grubu ortaokul çağındaki üstün yetenekli 191 ve normal gelişim gösteren 443 olmak üzere toplam 634 öğrenciden oluşmaktadır. Araştırmada nicel araştırma yöntemlerinden tarama deseni kullanılmıştır. Veri toplama aracı olarak "Fen Bilimleri Özyeterlik Ölçeği” kullanılmıştır. Araştırmada kullanılan ölçeğin güvenirlik katsayısı 0.917 olarak bulunmuştur. Verilerin analizi için bağımsız örneklem t-testi kullanılmıştı. Araştrma sonuçları ortaokul öğrencileri ile aynı düzeydeki üstün yetenekli öğrencilerin fen bilimleri özyeterlikleri arasında üstün yetenekli öğrenciler lehine anlamlı bir farklılık olduğunu göstermektedir. Çalışmada iki gruptaki öğrencilerin fen özyeterlikleri arasında ustalık, duyuşsal özellikler ve teşvik faktörleri açısından anlamlı bir farklılık olup olmadığını tespit etmek amacıyla, bu faktörler tek tek ele alınarak incelenmiştir. Sonuçta; uygulanan ölçekteki ustalık, duyuşsal özellikler ve teşvik faktörleri açısından üstün yetenekli öğrenciler lehine anlamlı farklılık olduğu görülmüştür. Her iki gruptaki ortaokul öğrencilerinin özyeterlik puanları cinsiyet değişkeni açısından incelendiğinde farklı cinsiyetteki öğrencilerin özyeterlik düzeyleri arasında anlamlı bir farklılık olmadığı görülmektedir.

Anahtar Kelimeler: üstün yetenekli öğrenciler, fen bilimleri, özyeterlik, cinsiyet

\section{Abstract}

The research's aim is to examine the effect of gender on science self-efficacy and science self-efficacy of gifted and nongifted middle school students. The research has been carried out at the education and training term of 2016-2017 in Melikgazi district of city of Kayseri. 634 students have constituted the total research sample, 191 of whom are gifted middle school students and the remaining 443 students are middle school students with normal development. Survey research, which is one of quantitative methods, has been implemented in the research. Likert Type "Science Self-Efficacy Scale" have been used as a data collecting tool. The reliability coefficient of scale used in the research has been found out as 0.917 . The independent sample t-test was used to data analysis. The results show that; there is a meaningful difference in behalf of gifted students between gifted middle school students and other middle school students' science self-efficacy scores. During the research, mastery, emotional and verbal factors have been studied one by one in order to find out if there is a meaningful difference between science self-efficacy levels of two groups of students in terms of three factors. In conclusion, a meaningful difference has been appeared on behalf of gifted students in terms of mastery, emotional and verbal. When the self-efficacy scores of the middle school students in both groups were examined in terms of gender variation, it was seen that there was no significant difference between the self-efficacy levels of the students of different sexes.

Keywords: gifted students, science, self-efficacy, gender

1. Bu çalışma, birinci yazarın ikinci yazar danışmanlığında hazırlamış olduğu yüksek lisans tezinden üretilmiştir.

2. Zenger Güç Ortaokulu, Kayseri, Türkiye ; https://orcid.org/0000-0002-1350-270X

3. Erciyes Üniversitesi, Eğitim Fakültesi, Kayseri, Türkiye; https://orcid.org/0000-0001-9023-7383

Atıf / Citation: Yıldırım, K. Ş., \& Saraçoğlu, S. (2019). Normal gelişim gösteren ve üstün yetenekli ortaokul öğrencilerinin fen bilimleri özyeterlikleri ve özyeterliklerine cinsiyetin etkisi. Kastamonu Education Journal, 27(3), 1291-1302. doi:10.24106/kefdergi.3061 


\section{Extended Summary}

Introduction: Self-efficacy expectations refer to one's beliefs about his or her ability to successfully perform specific tasks in specific situations. Self-efficacy affect what students do by influencing the choices they make, the expense they spend, the persistence and perseverance they exert when obstacles arise, and the thought patterns emotional reactions they experience. Self-efficacy beliefs support or difficult to reach a course's goals and achievements for students. Determination of self-efficacy levels of students is important in terms of qualified science education. Science teachers should act knowing the self-efficacy levels of their students in science. Also, knowledge of the sources of self-efficacy in students is important for the development of self-efficacy levels. In this way, self-efficacy improvement methods can be found in the teaching process. When the self-efficacy of the students in the middle school level is examined, gifted and nongifted students should be evaluated separately. Researchers believe that there is a strong link between gifted students and self-efficacy. While the self-efficacy perceptions of the students were examined in the field studies, it is stated that the role of the gender variable should be examined because it is one of the important variables affecting the student motivation. The research's aim is to examine the effect of gender on science self-efficacy and science self-efficacy of gifted and nongifted middle school students.

Method: Survey research, which is one of quantitative methods, has been implemented in the research. The research has been carried out at the education and training term of 2016-2017 in Melikgazi district of city of Kayseri. 634 students have constituted the total research sample, 191 of whom are gifted middle school students and the remaining 443 students are middle school students with normal development. There are 400 female and 234 male students in the survey. Likert Type "Science Self-Efficacy Scale" composing of 36 items have been used as a data collecting tool. According to results of pilot research, the scale has been revised and then have been used in research. It was determined that three of the factors determined for the self-efficacy scale were meaningful. The first factor is mastery, the second factor is emotional, the third factor is verbal. The reliability coefficient of the scale has been found as 0.917. Data has been evaluated via descriptive statistics and independent samples t-tests.

Results, Discussion and Suggestions: According to descriptive statistical results, scores from the scale are normal distribution. The results show that; there is a meaningful difference in behalf of gifted students between gifted middle school students and nongifted middle school students' science self-efficacy scores. According to the research, there is a positive relationship between students' mental competence of and self-efficacy beliefs. Studies in the literature support the fact that gifted students' self-efficacy is significantly different from nongifted. Students. One of the reasons why gifted middle school students' science self-efficacy is higher than nongifted middle school students is that these students have different educational practices in addition to their school activities. The science self-efficacy levels of middle school students are composed of three factors in the research. These are mastery, emotional and verbal. During the research, each factor has been studied one by one in order to find out if there is a meaningful difference between science self-efficacy levels of two groups of students in terms of three factors. In conclusion, a meaningful difference has been appeared on behalf of gifted students in terms of mastery, emotional and verbal. The high level of confidence of the gifted students might have been effective in this case. One of the reasons why gifted middle school students' science self-efficacy is meaningful higher than nongifted middle students in terms of emotional factor is that motivational characteristics of gifted students are more developed than the nongifted middle school students. Science teachers should be role models to students for develop self-efficacy levels of middle school students in terms of verbal factor. When the self-efficacy scores of the middle school students in both groups were examined in terms of gender variation, it was seen that there was no significant difference between the self-efficacy levels of the students of different sexes..This may be due to the fact that there may not be a restriction in terms of gender in our country. Another reason for this conclusion is that the self-efficacy can be fed from other sources such as experience, age, class level. Some studies in the literature support existing research results. Based on the results of the research, it is suggested that teachers should make plans in order to increase self-efficacy of especially nongifted secondary school students. Science teachers can use teaching methods and techniques that can improve the science self-efficacy levels of nongifted middle school students in science course. Research shows that applying different teaching methods increases the self-efficacy belief. In order to increase the science self-efficacy of the students with low self-efficacy, examples from the lives of scientists can be given. Moreover, the trainees can contribute to the increase of the self-efficacy levels of the students as role models to the students. In this study, the science self-efficacy levels of gifted and nongifted middle school students were compared in terms of gender variation. New research can be designed using different variables (grade level, parental occupations, socio-cultural structure, etc.) that are thought to affect secondary school students' self-efficacy levels. In addition, qualitative research can be planned using data collection tools such as observation and interviewing to provide in-depth knowledge of secondary school students' science self-efficacy levels. 


\section{Giriş}

Bireydeki benlik algısı, ilgi, motivasyon, özgüven, özyeterlik, özdüzenleme, kaygı ve tutum gibi bazı faktörler, bireyin bakış açısına etki etmekte ve bu bakış açısı, öğrencilerin bir dersin amaçlarına ve kazanımlarına ulaşmasını desteklemekte veya güçleştirmektedir (Abak, 2003; Bandura, 1995). Olumlu bir bakış açısı, bireyin kendisine daha büyük hedefler koymasına; almış olduğu kararlarında istikrarlı olmasına; böylece bilişsel düşünme süreci ve motivasyonlarının artmasına sebep olacaktır (Locke ve Latham, 1990). Öğrencinin bakış açısını oluşturan bu faktörlerin ayrı ayrı değerlendirilmesi gereklidir. Böylece öğretilecek konuya yönelik kişiye özel uyarıcılar geliştirilebilir ve verimliliği artırıcı tedbirler alınabilir (Yağbasan ve Gülçiçek, 2003).

Öğrencilerin bir derse ilişkin bakış açısını oluşturan değişkenlerden biri olan özyeterlik, kişinin, karşılaştğ̆ı görev veya sorunlara yönelik, belli bir performansı başarılı bir şekilde yapacağına dair kendisine olan inancıdır (Bandura, 1995). Özyeterlik, öğrencilerin hedef belirleme ve bu hedefe ulaşmada ne kadar çaba göstereceklerini belirleyen değişkenlerden biridir. Özyeterlik inancı, çok boyutlu olup farklı alanlarla bağlantlıdır ve öğrencinin değişik derslere yönelik özyeterlik inançları birbirinden farklıdır (Hazır Bıkmaz, 2002). Bu nedenle öğrencilerin her disipline ait özyeterliklerinin ayrı ayrı belirlenmesi gerekmektedir. Bir disipline ait özyeterlik inancı öğrencinin o disiplinde kendisini hangi seviyede başarılı ve yeterli gördüğ̈ ile alakalıdır (Zimmerman, 1995).

Bu kapsamda, öğrencilerin özyeterliklerinin incelenmesi gereken disiplinlerden biri de fen bilimleridir. Alan yazında güçlü özyeterliğe sahip bireylerin belirledikleri hedeflere karşı güçlü sorumluluk duygusu içerisinde oldukları, yanlış veya eksik yeterlik inancına sahip olanların ise bilimsel düşünme becerilerinin bu durumdan etkilendiği belirtilmektedir (Bandura, 1995). Öğrencilerin fen bilimleri özyeterliği ile ilgili olumsuz bir inancının bulunması fen bilimleri dersinin amaçlarına ve kazanımlarına ulaşmasını güçleştirir. Öğrenci, algıladığı olumsuz özyeterlik duygusunun baskısıyla, öğrenme sürecinde gerçek potansiyelini yansıtamaz. Alan yazında herhangi bir alanla ilgili özyeterliğin o alandaki başarı ile doğru orantılı olduğu da belirtilmiştir (Aktamış, Özenoğlu Kiremit ve Kubilay, 2016; Arkan, 2011; Çaycı, 2013; Ferla, Valcke ve Cai, 2009; Hızlıok, 2012; İsrael, 2007; Yenilmez ve Kakmacı, 2008; Yılmaz vd., 2012; Yurt, 2014). Dolayısıyla özyeterlik inancı, öğrencilerin bir dersin amaçlarına ve kazanımlarına ulaşmasını desteklemekte veya güçleştirmektedir. O halde öğrencilerin özyeterlik düzeylerinin belirlenmesi ve fen bilimleri öğretmenlerinin de, öğrencilerinin fen bilimlerine yönelik özyeterlik düzeylerini bilerek hareket etmesi nitelikli bir fen eğitimi açısından önemlidir.

Öğrencilerin sadece özyeterlik düzeyinin belirlenmesi yeterli olmayıp aynı zamanda bu düzeyin oluşmasına katkı sunan kaynakların da belirlenmesi gerekmektedir. Öğrencilerde fen bilimlerine yönelik özyeterliğin kaynaklarının bilinmesi özyeterlik düzeylerinin geliştirilmesi açısından önemlidir. Ancak bu sayede öğretim sürecinde özyeterliği geliştirici yöntemler bulunabilir (Kotaman, 2008). Araştırmada öğrencilerin fen bilimleri özyeterlik düzeylerinin ustalık, teşvik ve duyuşsal özellikler alt faktörleri açısından incelenmesi planlanmıştr. Bu faktörlerin ayrı ayrı değerlendirilmesi öğretmenlerin, öğrencilerdeki fen bilimleri özyeterliğinin geliştirilmesi açısından derslerinde özellikle ilgili faktörü dikkate alarak bireysel farklılıklara göre eğitim öğretim faaliyetlerini planlamalarına imkân verecektir. Böylece öğrenme-öğretme sürecini daha verimli hale getirmek ve eğitim kalitesini artırmak mümkün olabilecektir.

Alan yazın incelemesinde Türkiye'de bugüne kadar özyeterlik konusunu içeren çeşitli araştırmaların gerçekleştirildiği görülmektedir (Akbaş ve Çelikkaleli, 2006; Alabay, 2006; Berkant ve Ekici, 2007; Denizoğlu, 2008; Ekinci Vural ve Hamurcu, 2008; Ercan, 2007; Kahyaoğlu ve Yangın, 2007; Özkan, Tekkaya ve Çakıroğlu, 2002; Şahin Taşkın ve Hacıömeroğlu, 2010; Yaman, Cansüngü Koray ve Altunçekiç, 2004 ). Araştırmaların önemli bir kısmında özyeterlik inanç düzeyi öğretmen adayları açısından ele alınmıştı (Ekici, 2008; Feyzioğlu, Feyzioğlu ve Küçükçıngı, 2014; Hazır Bıkmaz, 2002; Karahan ve Uyanık Balat, 2011; Saracaloğlu ve Yenice, 2009).Yapılan araştrmalar incelendiğinde, ortaokul düzeyinde özyeterlik inancına yönelik sınırlı sayıda çalışma olduğu saptanmıştır (Çağırgan Gülten ve Soytürk, 2013; Kıran, 2010; Say, 2016; Yaman, 2016; Yılmaz, Yiğit ve Kaşarcı, 2012). Ortaokul dönemi, öğrencilerin meslek seçimi ve okul seçimi açısından ilgi ve yeteneklerini keşfettiği bir dönemdir. Öğrencilerin kendilerini bütünüyle algılayacak bir bakış açısına sahip olmaları, lise seçimlerini ve kariyer planlama noktasında hayatlarının yön vermelerini etkileyecektir. Ortaokul öğrencilerinin fen özyeterliklerini ortaya çıkararak lise seçimlerini yaparken de bu sonuçların göz önünde bulundurulması eğitimcilere doğru yönlendirme yapabilmeleri açısından katkı sağlayacaktı. Bu gerekçelerle çalışmada özyeterlik düzeyi, ortaokul seviyesindeki öğrenciler açısından ele alınmıştır.

Ortaokul seviyesindeki öğrencilerin özyeterlikleri incelenirken normal gelişim gösteren öğrenciler ile üstün yetenekli öğrencilerin ayrı ayrı değerlendirilmesi ve sonuçlarının karşılaştrılması gerekli görülmektedir. Özyeterlik inancı bireyin yaşamının farklı yönlerini etkilemekte; beceri, kabiliyet ve bilgi gibi diğer değişkenler arasında bağdaştırıcı rol oynamaktadır (Pajares ve Miller, 1994). Araştrrmacılar, üstün yetenekli öğrenciler ile özyeterlik arasında güçlü bağlar olduğuna 
inanmaktadırlar (Aksoy, 2014; Junge ve Dretzke, 1995). Dolayısıyla fen bilimleri gibi araşttrma, problem çözme, soru sorma, açıklama getirme ve eleştirel düşünmeyi gerektiren bir alanda üstün yetenekli öğrencilerin fen bilimleri özyeterliklerinin akranlarına göre ne düzeyde olduğunun belirlenmesi önem arz etmektedir. Bu nedenle çalışmada normal gelişim gösteren öğrenciler ile üstün yetenekli öğrencilerin fen bilimleri özyeterlikleri karşılaştrılmıştı. Öğrencilerin bakış açılarını oluşturan değişkenlerden biri olan özyeterliğin iki grup açısından ayrı ayrı değerlendirilmesi, hangi grubun özyeterliğinin geliştirilmesi gerektiği yönünde gerek ailelere, gerekse eğitimcilere yol gösterecektir. Bu durum öğrencilerin daha iyi anlaşılabilmesine ve doğru yönlendirilmesine katkı sağlayacaktır. Alan yazında üstün yetenekli öğrencilerin duyuşsal özelliklerini konu alan araştırmaların sınırlı sayıda olduğu görülmektedir (Akkaş ve Eker, 2013; Altun ve Yazıcı, 2012; Aşut, 2013; Kanlı, 2011; Özdemir, 2014; Ülger, Uçar ve Özgür, 2014). Araştrmacılar üstün yetenekli öğrencilerin özelliklerini konu alan araştırmaların arttııımasının alan yazını zenginleştireceğini belirtmektedirler (Güçin ve Oruç, 2015; Özenç ve Gül Özenç 2012).

Alan yazındaki araşttrmalarda öğrencilerin özyeterlik algıları incelenirken, öğrenci motivayonunu etkileyen önemli değişkenlerden biri olması nedeniyle cinsiyet değişkeninin rolünün de incelenmesi gerektiği belirtilmektedir (Aktamış, Özenoğlu Kiremit ve Kubilay, 2016; Arslan, 2017; Eccles, Wigfield, Harold ve Blumenfeld, 1993; Güvercin, Tekkaya ve Sungur, 2010; Pajares ve Miller, 1994). Cinsiyetin motivasyon üzerindeki etkisini inceleyen çalışmalar incelendiğinde, özyeterlik açısından kızlar ve erkekler arasında farklıklar olabildiğini ortaya koyan çalışmalar olduğu gibi (Aktamış, Özenoğlu Kiremit ve Kubilay 2016; Netz ve Raviv, 2004), aralarında farklılık olmadığını tespit eden çalışmaların da bulunduğu görülmektedir (Çetin, 2007; Hampton ve Mason, 2003). Alan yazında özyeterlik algısının cinsiyete göre incelendiği araştırma bulgularının farklılık göstermesi nedeniyle ortaokul düzeyindeki öğrencilerin fen özyeterlik inançlarının kapsamının belirlenebilmesi için özyeterlik ile cinsiyet arasındaki ilişkiyi inceleyen yeni araştırmalara intiyaç duyulmaktadır (Sakız, 2013; Yaman, 2016). Bu araştrrmanın amacı, normal gelişim gösteren ortaokul öğrencileri ile üstün yetenekli ortaokul öğrencilerinin fen bilimleri özyeterliklerini ve cinsiyetin öğrencilerin fen özyeterliklerine olan etkisini incelemektir.

\section{Yöntem}

\section{Araştırma Modeli}

Araştırmada nicel araştırma yöntemlerinden tarama deseni kullanılmıştır. Tarama deseni ile deneyimler sonucu oluştuğu düşünülen ve şuan var olan bir durum betimlenebilir; bir grubun belli özellikleri tespit edilebilir ve değişkenler arasında karşılaştırmalar yaparak sayısal veriler elde edilebilir (Büyüköztürk, Kılıç Çakmak, Akgün, Karadeniz ve Demirel, 2012). Bu araştırmada da üstün yetenekli öğrenciler ile normal gelişim gösteren ortaokul öğrencilerinin fen bilimleri özyeterlikleri karşılaştıııldığı için tarama deseni seçilmiştir.

\section{Çalışma Grubu}

Çalışmada rastgele olmayan örneklem çeşitlerinden uygun örnekleme yöntemi tercih edilmiştir. Araştırmanın çaIışma grubu olarak 2016-2017 eğitim-öğretim yılında Kayseri ili Melikgazi ilçesi 8. eğitim bölgesinde ve Kayseri ilindeki BiLSEM'de öğrenim gören toplam 740 öğrenci hedeflenmiştir. Uygulama sonrasında, bazı ölçeklerin uygun doldurulmamış olduğu (karikatür çizme, şiir yazma, not yazma vb.) tespit edilmiş ve bu ölçekler araştırmanın güvenirliğini olumsuz etkilememesi için değerlendirmeye alınmamıştır. Ayrıca, BiLSEM'de öğrenim gören tüm öğrenciler araştırma örneklemine dâhil edilmiş olmasına rağmen, bazı öğrencilerin sürekli devamsızlık yapmalarından dolayı bu öğrencilere çalışma takvimi çerçevesinde ölçek uygulanamamıştı. Araştırmanın çalışma grubunu 2016-2017 eğitim-öğretim yılında Kayseri ili Melikgazi ilçesi 8. Eğitim Bölgesinde 7 farklı ortaokulda öğrenim gören 443 ve bir Bilim ve Sanat Merkezinde öğrenim gören üstün yetenekli 191 olmak üzere 5., 6., 7. ve 8. Sınıfa giden toplam 634 tane ortaokul öğrencisi oluşturmaktadır. Öğrenci sayılarının sınıf düzeylerine ve cinsiyetlerine göre dağılımı Tablo 1'de gösterilmiştir.

\section{Tablo 1. Öğrenci sayılarının dağılımı}

\begin{tabular}{lcccccccc}
\hline Sınıf & \multicolumn{3}{c}{ Normal Gelişim Gösteren Ortaokul Öğrencileri } & \multicolumn{4}{c}{ Üstün Yetenekli Ortaokul Öğrencileri } \\
\cline { 2 - 9 } & Kız & Erkek & Toplam & $\%$ & Kız & Erkek & Toplam & $\%$ \\
\hline 5 & 77 & 34 & 111 & 25 & 22 & 27 & 49 & 25.7 \\
6 & 85 & 27 & 112 & 25.3 & 13 & 17 & 30 & 15.7 \\
7 & 80 & 32 & 112 & 25.3 & 27 & 41 & 68 & 35.6 \\
8 & 80 & 28 & 108 & 24.4 & 16 & 28 & 44 & 23 \\
\hline Toplam & 322 & 121 & 443 & 100 & 78 & 113 & 191 & 100 \\
\hline
\end{tabular}




\section{Veri Toplama Aracı}

Araştırmada Karaca, Bektaş ve Saraçoğlu (2016) tarafindan, ortaokul öğrencileri için geliştirilen geçerlik ve güvenirlik çalışması tamamlanmış 38 maddeden oluşan 5'li Likert tipi "Fen Bilimleri Özyeterlik Ölçeği" araştırmacılardan izin alınarak kullanılmıştır. Bu ölçeğin hem üstün yetenekli hem de normal gelişim gösteren ortaokul öğrencilerinde amaca hizmet edip etmediğini belirlemek için bir pilot çalışma yapılmıştı. Pilot çalışma; 2016-2017 eğitim öğretim yılında 398 üstün yetenekli ve 395 normal gelişim gösteren öğrenci olmak üzere toplam 793 ortaokul öğrencisi ile gerçekleştirilmiştir. Pilot çalışmada ölçeğin toplam puan normalliği, ayırt edicilik ve güçlük indeksleri belirlenmiş; bağımsız örneklemler t-testi ve betimsel istatistikleri yapılmıştr. Yapılan analizlerde ölçek maddelerinin frekans analizi sonucunda tepe değer 134, ortanca 139 ve ortalama 139 olarak bulunmuştur. Normal dağılımda aritmetik ortalama, tepe değer, ortanca değerleri birbirine yakındır. Çarpıklık -0.405; basıklık 0.305 olarak hesaplanmıştır. Bu sonuçlara bakılarak betimsel istatistik analizinin normal dağılım gösterdiği bulunmuştur. Madde güçlük indekslerine bakıldığında zor madde tespit edilememiştir. Madde güçlük indeksleri (p) 0.30 ile 0.70 değerleri arasında yer alan maddelerin istenilen özellikte olması nedeniyle ölçekte kalmasına karar verilmiştir. Ölçekte 0.70 'in üzerinde değer alan 1., 5. ve 17. maddelerin kolay olduğu söylenebilir. Madde ayırt edicilik indeksleri incelendiğinde, 13., 25. ve 29. maddelerin ayırt edicilik indekslerinin 0.20 değerinin altnnda olduğu yani ayırt ediciliklerinin düşük olduğu gözlenmiştir. t-testi sonuçları dikkate alınarak 13.ve 29. maddelerin ölçekten çıkartılmasına karar verilmiştir.

Araştırmada kullanılacak olan ölçekte yer alan birbiriyle ilişkili çok sayıda maddeleri bir araya getirerek kavramsal olarak anlamlı daha az sayıda yeni maddeler (faktörler) oluşturmak amacıyla açımlayıcı faktör analizi yapılmıştr. Burada amaç yeni bir ölçek geliştirmekten ziyade var olan geçerlik ve güvenirliği yapılmış bir ölçekteki değişken sayısını azaltarak yeni yapılar ortaya çıkarmaktır. Bu süreçte üretilen bilgilerin doğrulanmasından ziyade sadece verilerinin temelini oluşturan faktörün bir hipotez için yeterli olup olmadığına karar vermek ve faktörlerin sayısını tespit etmek amaçlandığı için sadece açımlayıcı faktör analizi kullanılmıştır. Bu kapsamda analizden önce araştırmacılar tarafindan bir hipotezin kurulması ve bunun test edilmesi amaçlanmadığı için doğrulayıcı faktör analizi gerçekleştirilmemiştir (Büyüköztürk vd., 2012). Araştrrmada kullanılan ölçeğin faktör analizinde Kaiser-Meyer-Olkin (KMO) değeri ve Bartlett küresellik testi değerleri hesaplanmıştr. KMO testi sonucu 0.937 olarak bulunmuştur ve bu değer 0.7 'nin üzerinde olduğu için iyi olarak yorumlanmıştir (Can, 2016). Bartlett testi sonucu p değeri .000 olarak bulunmuştur. Bu değer .05 'ten küçük olduğu için değişkenler arasında faktör analizi yapılabilecek seviyede ilişki mevcuttur (Can, 2016). Bu sonuçlara göre faktör analizi yürütülebilirdir. Varimax döndürme yöntemi kullanılarak yapılan analizlerde özyeterlik ölçeği için tespit edilen faktörlerden üçünün anlamlı olduğu belirlenmiştir. Yapılan analizlerde yük değeri 0.30'un altında kalan maddeler ihmal edilmiştir. Maddenin hangi faktörün altında yer alacağına karar verilirken yük değerlerinden büyük olan faktör tercih edilmiştir. Faktör analizi sonucunda bulunan üç faktörün, maddelerdeki toplam varyansın ve ölçeğe ilişkin varyansın yaklaşık \% 40.4'lük kısmını açıkladığı belirlenmiştir. Birinci faktör toplam varyansın yaklaşık \%14,5'ini; ikinci faktör toplam varyansın yaklaşık \% 13,4'ünü ve üçüncü faktör toplam varyansın yaklaşık \%12,5'ini açıklamaktadır. Gerçek deneyimler sonucu bireyin başarıya ulaşmak için gösterdiği çabayı temsil birinci faktör ustalık (mastery) olarak adlandırılmış olup, 1, 17, 22, 24, 30, 31, 32, 33, 34, 35, 36, 37, 38 numaralı maddeler birinci faktör altında toplanmıştır. 3, 5, 6, 7, 8, $12,14,15,16,18,23,26,28$ numaralı maddeler duyuşsal özellikler (emotional) olarak adlandırılan ikinci faktör altında toplanmıştır. Duyuşsal özellikler faktörü insanların özyeterlik inançlarının stres, yorgunluk, ruh hali, gerginlik, duygu, ağrı gibi durumlardan etkilenip etkilenmediğini gösteren durumları temsil eder. Üçüncü faktör altında toplanan 2, 4, $9,10,11,19,20,21,25,27$ numaralı maddeler teşvik (cesaret, verbal) olarak adlandırılmıştır. Bu faktör bireyin insanlar tarafindan desteklenmesi ya da teşvik edilmesi gibi durumları kapsar. Gerçekleştirilen analizler sonucunda belirlenen faktörler, faktörlere ait maddeler ve faktör yük değerleri Tablo 2'de verilmiştir.

Tablo 2. Fen Bilimleri Özyeterlik Ölçeğinin Faktör Analizi Sonuçları

\begin{tabular}{lclccc}
\hline \multicolumn{2}{c}{ Faktör 1: Ustalık } & \multicolumn{2}{c}{ Faktör 2: Duyuşsal Özellikler } & \multicolumn{2}{c}{ Faktör 3: Teşvik } \\
\hline Madde No & $\begin{array}{c}\text { Faktör Yük } \\
\text { Değerleri }\end{array}$ & Madde No & $\begin{array}{c}\text { Faktör Yük } \\
\text { Değerleri }\end{array}$ & Madde No & $\begin{array}{c}\text { Faktör Yük } \\
\text { Değerleri }\end{array}$ \\
\hline Madde 35 & .674 & Madde 8 & .691 & Madde 27 & .595 \\
Madde 32 & .628 & Madde 12 & .656 & Madde 9 & .593 \\
Madde 38 & .594 & Madde 23 & .590 & Madde 21 & .562 \\
Madde 1 & .579 & Madde 5 & .560 & Madde 11 & .520 \\
Madde 24 & .570 & Madde 28 & .553 & Madde 19 & .519
\end{tabular}




\begin{tabular}{lccccc}
\hline \multicolumn{2}{c}{ Faktör 1: Ustalık } & \multicolumn{2}{c}{ Faktör 2: Duyuşsal Özellikler } & \multicolumn{2}{c}{ Faktör 3: Teşvik } \\
\hline Madde No & $\begin{array}{c}\text { Faktör Yük } \\
\text { Değerleri }\end{array}$ & Madde No & $\begin{array}{c}\text { Faktör Yük } \\
\text { Değerleri }\end{array}$ & Madde No & $\begin{array}{c}\text { Faktör Yük } \\
\text { Değerleri }\end{array}$ \\
\hline Madde 34 & .568 & Madde 3 & .541 & Madde 10 & .510 \\
Madde 30 & .487 & Madde 7 & .538 & Madde 25 & .503 \\
Madde 37 & .486 & Madde 14 & .515 & Madde 4 & .488 \\
Madde 31 & .483 & Madde 18 & .515 & Madde 2 & .448 \\
Madde 17 & .465 & Madde 26 & .429 & Madde 20 & \\
Madde 36 & .464 & Madde 15 & .423 & & .415 \\
Madde 22 & .454 & Madde 16 & & \\
Madde 33 & .384 & Madde 6 & .406 & & \\
\hline
\end{tabular}

Araştırmada kullanılan ölçeğin orjinal halinin güvenirlik katsayısı 0.91'dir. Çalışmada kullanılan 36 maddeden oluşan 5’li Likert tipi “Fen Bilimleri Özyeterlik” ölçeğinin Cronbach Alpha güvenirlik katsayısı 0,917 olarak hesaplanmıştr. Faktörlerin güvenirlik katsayıları ise; ustalık faktörü için 0.873 , duyuşsal özellikler faktörü için 0.836 , teşvik faktörü içinse 0.775 olarak hesaplanmıştır. Faktörlere ait güvenirlik katsayısı ayrı ayrı incelendiğinde üç faktörün de güvenirlik katsayılarının 1'e yakın olduğu görülmektedir. Bu durum; üç faktörün de güvenirliğinin yüksek olduğunu göstermektedir.

\section{Verilerin Analizi}

Veriler 2016-2017 eğitim-öğretim yılının güz ve bahar yarıyılında toplanmış ve verilerin toplanması 10 hafta sürmüştür. Fen bilimleri özyeterlik ölçeğindeki puanların betimsel istatistik sonuçları: Ortalama 131.5; ortanca 134.2; tepe değer 135; standart sapma 22.36; çarpıklık -0.584; basıklık 0.305 olarak hesaplanmıştır. Tepe değer, ortanca ve ortalama değerleri karşılaştrıldığında, bu değerlerin birbirine yakın olduğu görülmektedir ve bu durum normal dağılımın bir göstergesidir. Bu ölçekte katılımcıların puan aralığına ilişkin çarpıklık ve basıklık değerleri -1 ve +1 arasında olduğundan bu ölçekten alınan puanlar da normal dağılım göstermektedir. Araştırmada normal gelişim gösteren ve üstün yetenekli ortaokul öğrencilerinin fen bilimleri özyeterlik inançları arasında anlamlı fark olup olmadığının ve öğrencilerinin fen bilimleri özyeterlik inançlarının cinsiyet değişkenine göre anlamlı şekilde farklılaşıp farklılaşmadığının belirlenmesi amacıyla bağımsız örneklem t-testi kullanılmıştır.

\section{Bulgular}

Öğrencilerin fen bilimleri özyeterlik düzeylerinin iki grup arasındaki karşılaştırması bağımsız örneklem $t$-testi kullanılarak yapılmıştr. Bu karşılaştırmada iki grubun özyeterlik düzeyleri hem genel hem de faktörler açısından ayrı ayrı değerlendirilmiştir. Elde edilen sonuçlar Tablo 3'te verilmiştir.

Tablo 3. Normal gelişim gösteren ve üstün yetenekli ortaokul öğrencilerinin fen bilimleri özyeterlik düzeylerine ilişkin bağımsız örneklem t-testi sonuçları

\begin{tabular}{|c|c|c|c|c|c|c|c|}
\hline & Gelişim Düzeyi & $\mathrm{N}$ & $\bar{X}$ & SS & Sd & $\mathrm{t}$ & $\mathrm{p}$ \\
\hline \multirow[t]{2}{*}{ Genel } & Normal Gelişim Gösteren Ortaokul Öğrencileri & 443 & 127.1 & 22.24 & \multirow{2}{*}{416} & \multirow{2}{*}{-8.43} & \multirow{2}{*}{$.00^{*}$} \\
\hline & Üstün Yetenekli Ortaokul Öğrencileri & 191 & 141.8 & 19.10 & & & \\
\hline \multirow[t]{2}{*}{ Ustalık Faktörü } & Normal Gelişim Gösteren Ortaokul Öğrencileri & 443 & 50.08 & 10.12 & \multirow{2}{*}{456} & \multirow{2}{*}{-4.54} & \multirow{2}{*}{$.00^{*}$} \\
\hline & Üstün Yetenekli Ortaokul Öğrencileri & 191 & 53.48 & 7.90 & & & \\
\hline \multirow{2}{*}{$\begin{array}{l}\text { Duyuşsal Özel- } \\
\text { likler Faktörü }\end{array}$} & Normal Gelişim Gösteren Ortaokul Öğrencileri & 443 & 45.01 & 8.68 & \multirow{2}{*}{377} & \multirow{2}{*}{-10.84} & \multirow{2}{*}{$.00^{*}$} \\
\hline & Üstün Yetenekli Ortaokul Öğrencileri & 191 & 52.91 & 8.28 & & & \\
\hline \multirow[t]{2}{*}{ Teşvik Faktörü } & Normal Gelişim Gösteren Ortaokul Öğrencileri & 443 & 32.01 & 7.02 & \multirow{2}{*}{421} & \multirow{2}{*}{-6.21} & \multirow{2}{*}{$.00 *$} \\
\hline & Üstün Yetenekli Ortaokul Öğrencileri & 191 & 35.40 & 5.95 & & & \\
\hline
\end{tabular}

Üstün yetenekli ortaokul öğrencileri 191, normal gelişim gösteren ortaokul öğrencileri 443 kişi olduğu için varyansların homojenliği söz konusu değildir. Levene testi anlamlılık değeri .001 bulunmuş ve bu değer .05 'ten küçük olduğu için varyansların homojen olmadığı belirlenmiştir. Varyansların homojen olmaması dikkate alınarak analiz tablosu okunmuştur. Sonuçlar göstermektedir ki; iki grubun fen bilimleri özyeterlik puanları arasında üstün yetenekli öğrenciler lehine anlamlı bir farklılık vardır $\left(\mathrm{t}_{(416)}=-8.43, \mathrm{p}<.05\right)$. Ayrıca iki grup arasında ustalık faktörü açısından $\left(\mathrm{t}_{(456)}=-4.54, \mathrm{p}<.05\right)$; 
duyuşsal özellikler faktörü açısından $\left(t_{(377)}=-10.84, p<.05\right)$ ve teşvik faktörü açısından da $\left(t_{(421)}=-6.21, p<.05\right)$ üstün yeteneklilerin lehine anlamlı bir farklılık tespit edilmiştir.

Araştırmada etki büyüklüğü incelendiğinde iki grup arasında özyeterlik puanlarının Cohen's d değeri 0.70 olup orta düzeyde etkili olduğu görülmüştür $(0.80>d>0.50)$. Ustalık faktörü açısından Cohen's d değeri 0,37 olarak hesaplanmış olup küçük etki olarak değerlendirilmiştir ( $0.50>d>0.20)$. Duyuşsal özellikler fakötürü açısından Cohen's d değeri 0.93 olup büyük etkiye sahiptir ( $d>0.80)$. Teşvik faktörü açısından Cohen's $d$ değeri $0.52(0.80>d>0.50)$ olup orta etkiye sahip olarak değerlendirilmiştir (Green ve Salkind, 2005).

Normal gelişim gösteren ve üstün yetenekli ortaokul öğrencilerinin fen bilimleri özyeterlik inançlarının cinsiyet değişkenine göre anlamlı şekilde farklılaşıp farklılaşmadığının belirlenmesi amacıyla uygulanan bağımsız örneklem $t$-testi sonucunda elde edilen bulgular Tablo 4'te sunulmuştur.

Tablo 4. Normal gelişim gösteren ve üstün yetenekli ortaokul öğrencilerinin fen bilimleri özyeterlik düzeylerinin cinsiyete göre farklıı̆ı̆ına ilişkin $t$-testi sonuçları

\begin{tabular}{lccccccc}
\hline Gelişim Düzeyi & Cinsiyet & $\mathrm{N}$ & $\overline{\mathrm{X}}$ & $\mathrm{SS}$ & $\mathrm{Sd}$ & $\mathrm{t}$ & $\mathrm{p}$ \\
\hline Normal Gelişim Gösteren Ortaokul Öğrencileri & Kız & 322 & 127.8 & 21.07 & \multirow{2}{*}{187} & \multirow{2}{*}{0.998} & \multirow{2}{*}{.320} \\
& Erkek & 121 & 125.3 & 25.08 & & & \\
Üstün Yetenekli Ortaokul Öğrencileri & Kız & 78 & 140.7 & 16.36 & \multirow{2}{*}{189} & \multirow{2}{*}{0.674} & \multirow{2}{*}{.501} \\
& Erkek & 113 & 142.6 & 20.83 & & \\
\hline
\end{tabular}

Normal gelişim gösteren öğrencilerde iki grunun varyansları arasında anlamlı düzeyde fark vardır ve varyanslar homojen değildir. $t$-testi sonuçlarına göre kız öğrencilerin özyeterlik düzeyleri (Ort=127.8, SS=21.07) erkek öğrencilerin özyeterlik düzeylerinden (Ort=125.3, SS=25.08) daha yüksektir, ancak aralarındaki fark anlamlı düzeyde değildir $\left(t_{187}=0.998, p>.05\right)$. Üstün yetenekli öğrencilerde Levene's testi sonuçlarına göre iki grubun varyansları homojendir. Tablo 4'ten görüldüğü gibi kız öğrencilerin özyeterlik düzeyleri (Ort=140.07, SS=16.36) erkek öğrencilerin özyeterlik düzeylerinden (Ort=142.6, SS=20.83) daha düşüktür, ancak aralarındaki fark anlamlı düzeyde değildir $\left(\mathrm{t}_{189}=0.674, \mathrm{p}>.05\right)$.

\section{Sonuç ve Öneriler}

Normal gelişim gösteren ortaokul öğrencileri ile üstün yetenekli ortaokul öğrencilerinin fen bilimleri özyeterlik düzeylerini ve özyeterlik düzeylerinin cinsiyet ile değişimini karşılaştırmak amacıyla yapılan nicel araştırma Kayseri ilindeki 634 ortaokul öğrencisi ile gerçekleştirilmiş olup elde edilen veriler bağımsız örneklem t-testi kullanılarak değerlendirilmiştir.

Araştırma sonuçları normal gelişim gösteren ortaokul öğrencileri ile aynı düzeydeki üstün yetenekli öğrencilerin fen bilimleri özyeterlik düzeyleri arasında üstün yetenekli öğrenciler lehine anlamlı bir farklılık olduğunu göstermektedir. Altun ve Yazııı (2012), üstün yetenekli öğrencilerin akademik özyeterlik puanlarının normal gelişim gösteren öğrencilerinkinden anlamlı düzeyde yüksek olduğunu tespit etmişlerdir. Elde edilen sonuçlar bakımından mevcut çalışma bu çalışma sonuçları ile benzerlik göstermektedir. Aksoy da (2014) üstün yetenekli öğrencilerle normal gelişim gösteren öğrencilerin akademik özyeterliklerini karşılaştrrmıştı. Çalışma sonucunda BiLSEM'de öğrenim gören üstün yetenekli öğrencilerin Türkçe, Matematik, Fen Bilgisi ve Sosyal Bilgiler derslerine yönelik akademik özyeterlik algılarının normal gelişim gösteren öğrencilere göre oldukça fazla olduğu belirlenmiştir. Aksoy'un (2014) çalışması ilkokul 4. sınıf öğrencilerine yapılmış olsa da üstün yetenekli öğrencilerin fen bilimlerine yönelik akademik özyeterliklerinin normal gelişim gösteren öğrencilere göre anlamlı şekilde yüksek olduğunun tespit edilmesi yönüyle mevcut araştrrmayla benzerlik göstermektedir. Alan yazında, öğrencilerin zihinsel yeterlikleri ile özyeterlik inançları arasında oldukça pozitif ilişkiler olduğu sonucunu ortaya koyan araştırmalar bulunmaktadır (Pajares, 1996; Zimmerman, Bandura ve Martinez-Pons, 1992). Ayrıca yapılan araştırmalarda özyeterlik algısının, kişinin yaşamında önemli bir yeri bulunan bilişsel süreçleri, davranışa bakış açısını ve davranışını etkilediği de belirtilmektedir (Balyan, 2009; Bandura, 1995; Locke ve Latham, 1990). Bu çalışmalar, yapılan araştırmada elde edilen üstün yetenekli öğrencilerin özyeterliklerinin üstün yetenekli olmayan akranlarından anlamlı düzeyde farklı olması sonucunu destekler niteliktedir. Ayrıca alan yazında üstün yetenekli olmanın sadece yüksek zekâya sahip olmak anlamına gelmediği, üstün yetenekli öğrencilerin yüksek güdülenme yani görev sorumluluğu bilincine sahip oldukları, bir başkası tarafindan güdülenmeye ihtiyaçlarının olmadığı belirtilmektedir (Kahyaoğlu ve Pesen, 2013). Üstün yetenekli öğrencilerin özellikleri ile özyeterlik düzeyi gelişmiş bireylerde bulunması gereken özellikler arasındaki benzerliğe yönelik yapılan bu açıklamalar, araştırmada elde edilen üstün yetenekli öğrencilerin özyeterlik inancının normal öğrencilerden anlamlı düzeyde farklı olması sonucunu desteklemektedir.

Üstün yetenekli öğrenciler, okullarında aldıkları eğitime ek olarak BíLSEM'lerde de eğitim almaktadırlar. Araştır- 
ma sürecinde BíLSEM'lerde görevli eğitimcilerle yapılan görüşmelerde, bu okullarda; robotik çalışmalar, bilimsel süreç becerileri, laboratuvarı etkin kullanma, proje geliştirme, bilim tarihi ve felsefesi gibi konuları da içerecek şekilde; öğrencilerin normal okullarında aldıkları eğitimin daha üst seviyesinde bir eğitim aldıkları öğrenilmiştir. Üstün yetenekli ortaokul öğrencilerinin fen bilimleri özyeterliklerinin ortaokul öğrencilerinden yüksek çıkmasının nedenlerinden biri bu öğrencilerin ilgili okullarda almış oldukları bu tür farklı eğitim uygulamaları olabilir. Ülger vd.'nin (2014) yapmış oldukları çalışmada elde edilen sonuçlar bu görüşü destekler niteliktedir. Bu araştırmada üstün yetenekli öğrenciler BíLSEM'de aldıkları fen eğitiminin, fen bilimlerini eğlenceli bulmalarına ve fen bilimleri alanını daha fazla tanımalarına katkı sağladığını, bazı kişisel özelliklerinin geliştiğini ve deneyimlerini artırdığını belirtmişlerdir.

Çalışmada normal gelişim gösteren ortaokul öğrencileri ve üstün yetenekli ortaokul öğrencilerinin fen bilimleri özyeterlik düzeyleri arasında ustalık, duyuşsal özellikler ve teşvik faktörleri açısından anlamlı bir farklılık olup olmadığını tespit etmek amacıyla özyeterlik düzeyleri iki grup açııından tek tek faktörler ele alınarak incelenmiştir. Özyeterlik inancına etki eden faktörlerden biri olan ustalık faktörü, yaşant yoluyla bireyin başarıya ulaşmak için gösterdiği çabayı ifade eder. Bir başka deyişle ustalık, bireylerin karşılaştkkları zorlukların üstesinden gelebileceklerine olan inançlarını oluşturan deneyimleridir. Bireydeki özyeterlik inanıının yüksek olması onların bilişsel düşünme süreçlerini etkileyerek, güçlü bir akademik performansa ve yüksek zihinsel yeterliklere neden olabilmektedir (Hampton ve Mason, 2003; Pajares, 1996; Pintrich, 1999; Zimmerman vd., 1992). Mevcut çalışmada da üstün yetenekli öğrencilerin özyeterlikleri ustalık faktörü açısından ortaokul öğrencilerine göre anlamlı düzeyde farklı bulunmuştur. Üstün yetenekli öğrencilerin kendilerine olan güvenlerinin yüksek olması bu durumda etkili olmuş olabilir. Bu inancın üstün yetenekli öğrencilerde yüksek olmasının sebeplerinden birisi de bu öğrencilere yönelik BiLSEM'lerde normal okullarda verilen eğitimden farkIılaştrıımış eğitim programlarının uygulanması ve öğrencilerin özel yeteneklerini geliştirici faaliyetlerin içerisinde yer almalarına yönelik geçirmiş oldukları yaşantılar olabilir.

Mevcut çalışmada elde edilen sonuçlardan bir diğeri de ortaokul çağındaki üstün yetenekli öğrencilerin fen bilimlerine yönelik özyeterliklerinin duyuşsal özellikler açısından normal gelişim gösteren ortaokul öğrencilerine göre anlamlı düzeyde farklı bulunmasıdır. Bu durumun sebeplerinden biri, üstün yetenekli öğrencilerin güdülenmelerinin diğer ortaokul öğrencilerinden daha fazla gelişmiş olması olabilir. Kahyaoğlu ve Pesen'nin (2013) yapmış oldukları araşttrmada elde edilen, üstün yetenekli öğrencilerin yüksek güdülenmeye sahip oldukları sonucu bu düşünceyi destekler niteliktedir. Kaya, Kanık ve Alkın da (2016) yaptıkları araştırmada, ortaokul çağındaki üstün yetenekli öğrencilerin duygusal zekâ puanlarının normal gelişim gösteren öğrencilerden daha yüksek olduğunu tespit etmişlerdir. Bu çalışmada elde edilen sonuçlar da mevcut araştırma sonuçlarını desteklemektedir. Üstün yetenekli bireylerin iradeli olma, zorlukla başa çıkma, yaratıc fikirler üretmeye açık olma, içten denetimli olma, azimli ve sabırlı olma, kaderci olmama, yeni ortaya çıkan durumlara kolay uyum sağlama gibi güdüsel özellikleri, özyeterlik düzeyi gelişmiş bireylerde olması gereken özellikler ile büyük oranda benzerlik göstermektedir (Baykoç, 2012). Çalışma sonuçlarından bir diğeri de ortaokul öğrencilerinin özyeterlik düzeyinin teşvik faktörü açısından aynı düzeydeki üstün yeteneklilere göre daha düşük düzeyde olmasıdır. Araştırmacılar fen bilimleri özyeterlik düzeylerinin teşvik ile artacağını belirtmektedirler (Karaarslan ve Sungur, 2011; Uçak ve Bağ 2012). Eğitimciler öğrencileri, fen okuryazarlığının önemi hakkında bilgilendirmeli; kaynaklara ulaşma konusunda yönlendirmeler yapmalı ve kendileri de rol model olmalıdırlar. Bu uygulamalar yapıldığında, "Fen Bilimleri Özyeterlik Ölçeğindeki" teşvik faktörü de olumlu yönde etkilenebilir ve öğrencilerin özyeterlik düzeylerinin artmasına katkı sağlayabilir. Ayrıca öğretmenler teşvik faktörü açısından öğrencilerin özyeterlik düzeylerinin geliştirilmesi için öğrencilere hem gayret hem de yeteneklerine dönük geri bildirimler vermelidirler. Sadece çabalarına yönelik geri dönütler verildiğinde öğrenciler yeteneklerini fark edemeyebilir ya da kendilerini yetersiz hissedebilirler. Bununla beraber sadece yeteneklerine yönelik dönütler verilirse öğrenciler çaba sarf etmeden başarılı olacaklarını zannedebilirler. Bu iki kavram da teşvik faktörünü etkileyen önemli ayrıntılardır.

Bulgular incelendiğinde, her iki gruptaki ortaokul öğrencilerinin özyeterlik puanları arasında cinsiyet değişkeni açısından anlamlı bir farklılık olmadığı görülmektedir. Bu sonucun ortaya çıkmasında ülkemizde cinsiyetler açısından bir sınırlamanın olmaması etkili olmuş olabilir. Öğrencilerin özyeterliklerinin cinsiyet açııından farklılaşmamasının bir diğer nedeni, özyeterliğin deneyim, sosyal ikna, yaş, sınıf düzeyi gibi başka kaynaklardan beslenmesi ve hiçbir değişkenin tek başına öz yeterliği büyük ölçüde etkilemeyişi olabilir. Ayrıca bu sonuç, fen derslerinde kız ve erkek öğrencilerin aynı gruplarda yer aldığı işbirlikli çalışma gruplarının oluşturulması ve sınıf içi etkinliklerde hem kız hem de erkek öğrencilere yönelik yaşantılara yer verilmiş olması intimalini düşündürmektedir. Alan yazında yer alan cinsiyet ve öz yeterlik arasındaki ilişkiyi inceleyen bazı araştırmalarda ilk ve ortaöğretim öğrencilerinin özyeterlik düzeyinin cinsiyete göre farklılaşmadığı sonucuna ulaşılmıştır (Ekinci, 2011; Sinan, Şardağ, Salifoğlu, Çakır ve Karabacak, 2014). Benzer biçimde, Hampton ve Mason (2003) da, lise öğrencilerinde cinsiyet değişkeninin özyeterlik ve kaynaklarını etkilemediğini tespit etmişlerdir. Bu araştırmaların sonuçları mevcut araştırma sonuçlarını desteklemektedir. Öte yandan, alan yazında 
cinsiyete göre özyeterlik düzeyinin farklılaştı̆ı sonucuna ulaşan çalışmalar da bulunmaktadır. (Arslan, 2017; Britner ve Pajares, 2001; Güvercin, Tekkaya ve Sungur, 2010; Koç ve Arslan, 2017; Usher ve Pajares, 2006; Yılmaz, Yiğit ve Kaşarcl, 2012). Bu çalışmalarda, özyeterlik düzeyini kızlar lehine anlamlı düzeyde farkıı bulunmuştur. Bu durum geleneksel kadın rollerinin değişmesi ve kadınların toplumda akademik başarıları ile ön plana çıkmaları gibi faktörlerle açıklanmıştır. Bu çalışmalardan farklı olarak alan yazında özyeterlik düzeyinin erkekler lehine olduğunu gösteren çalışmalar da bulunmaktadır (Netz ve Raviv, 2004; Say, 2005). Bu araştırmaların genellikle yetişkin bireylerle yapıldığı görülmektedir. Mevcut araştırmada ortaokul öğrencileri ile çalışılıı̆ı için bu çalışmalarla karşılaştırma yapmak net bir durum ortaya koymayı zorlaştracaktır.

Sonuç olarak yapılan araştırmada normal gelişim gösteren ortaokul öğrencilerinin fen bilimleri özyeterlik düzeylerinin üstün yetenekli ortaokul öğrencilerinden anlamlı düzeyde düşük olduğu tespit edilmiştir. Bu nedenle eğitimcilerin özellikle normal gelişim gösteren ortaokul öğrencilerinin özyeterliklerini artırmaya yönelik olarak planlama yapmaları gerekmektedir. Özyeterliğin değişen ve gelişen bir kavram olduğu göz önünde bulundurulursa; fen bilimleri öğretmenleri, bu araşttrmada elde edilen veriler doğrultusunda; öğrencilerinin fen bilimlerine yönelik özyeterlik düzeylerini geliştirebilecek öğretim yöntem ve tekniklerini belirleyebilirler. Bu durum daha nitelikli bir fen eğitimi verilmesi firsat sağlayacaktır. Araştırmalar farkılıştrıımış öğretim yöntemleri uygulanmasının özyeterlik inancını anlamlı bir şekilde arttırdığını göstermektedir (Arslan, 2011; Chang, 1997; Hall ve Ponton, 2005; Tuğran, 2015; Ural, Umay ve Argün, 2008; Yabas, 2008; Yenilmez ve Uygan, 2010). Bandura (1995) öğrencilerin özyeterliklerini etkileyen unsurlardan birinin de modelleme olduğunu belirtmiștir. Bilim insanlarının hayatlarında olumsuzluklara rağmen pes etmemeleri, çabaları, sabırla başladıkları işi bitirmeleri, yeni oluşan durumlara uyum sağlamaları, hayal güçlerini kullanarak belirledikleri hedefleri, bu hedeflere ulaşma istekleri ve sonuçta elde ettikleri başarılar öğrencileri etkileyebilir. Bu sebeple topluma ya da dünyaya örnek olmuş bilim insanlarının hayatlarından, çabalarından ve başarılarından örnekler verilebilir. Böylece akademik özyeterliği düşük olan öğrencilerde bir farkındalık durumu yaratılarak özyeterlikleri geliştirilebilir.

Özyeterliğin sadece eğitim-öğretim sürecinde değil, bireylerin tüm yaşantları boyunca hayatının her alanında kendini hissettiren bir kavram (Balyan, 2009) olması dolayısıyla öğrencilerin yaşamları boyunca ustalık yetenekleriyle özel inanışlar ve buna göre davranış değişiklikleri geliştirebilecekleri ifade edilebilir. Çalışmada elde edilen sonuca dayanarak özellikle normal gelişim gösteren ortaokul öğrencilerinin özyeterlik inancını geliştirmek için ruh halini olumsuz etkileyecek duygusal eğilimleri azaltmak gerektiği söylenebilir. Bandura da (1995) özyeterlik inancının duygusal durumlar etkisi ile gelişebileceğini belirtmektedir. Ayrıca eğitimciler öğrencilere rol model olarak öğrencilerin özyeterlik düzeylerinin artmasına katkı sağlayabilir. Bunun yanı sıra öğretmenler teşvik faktörü açısından öğrencilerin özyeterlik düzeylerinin geliştirilmesi için öğrencilere hem gayret hem de yeteneklerine dönük geri bildirimler vermelidirler. Bu iki kavram da teşvik faktörünü etkileyen önemli ayrıntılardır.

Bu araştrrmada normal ve üstün yetenekli ortaokul öğrencilerinin fen bilimleri özyeterlik düzeyleri cinsiyet değişkeni açısından karşılaştrılmıştı. Ortaokul öğrencilerinin fen bilimleri özyeterlik düzeylerini etkileyeceği düşünülen farklı değişkenler kullanılarak (sınıf düzeyi, ebeveyn meslekleri, ebeveyn öğrenim bilgileri, sosyo-kültürel yapı vb.) yeni araştrrmalar tasarlanabilir. Ayrıca ortaokul öğrencilerinin fen bilimleri özyeterlik düzeyleri hakkında derinlemesine bilgi edinebilmek adına gözlem ve görüşme gibi veri toplama araçları kullanılarak nitel araştırmalar planlanabilir.

\section{Kaynakça}

Abak, A. (2003). Modeling the relationship between university students' selected affective characteristics and their physics achievement (Yayımlanmamış Yüksek Lisans Tezi). Ortadoğu Teknik Üniversitesi, Ankara.

Akbaş, A. ve Çelikkaleli, Ö. (2006). Sınıf öğretmeni adaylarının fen öğretimi özyeterlik inançlarının cinsiyet, öğrenim türü ve üniversitelerine göre incelenmesi. Mersin Üniversitesi, Eğitim Fakültesi Dergisi, 2(1), 98-110.

Akkaş, E. ve Eker C. (2013). Bilim ve sanat merkezlerine devam eden üstün yetenekli öğrencilerin başarı durumları. Üstün Yetenekliler Eğitimi Araştırmaları Dergisi, 1(1), 44-50.

Aktamış, H., Özenoğlu Kiremit, H. ve Kubilay, M. (2016). Öğrencilerin öz-yeterlik inançlarının fen başarılarına ve demografik özelliklerine göre incelenmesi. Adnan Menderes Üniversitesi Eğitim Fakültesi Eğitim Bilimleri Dergisi, 7(2), 1-10.

Aksoy, Ö. (2014). Üstün zekalı ve normal öğrencilerin algılanan akademik öz-yeterliklerinin karşılaştrılması. Üstün Zekalılar Eğitimi ve Yaratıcılık Dergisi, 1(1), 1-6.

Alabay, E. (2006). İlköğretim okulöncesi öğretmen adaylarının fen ile ilgili öz yeterlik inanç düzeylerinin incelenmesi. Yeditepe Üniversitesi Eğitim Fakültesi Dergisi, 2 (1).

Altun, F. ve Yazıcı, H. (2012). Üstün yetenekli öğrencilerin benlik kavramları ve akademik öz-yeterlik inançları: karşılaştırmalı bir çalışma. Mehmet Akif Ersoy Üniversitesi Eğitim Fakültesi Dergisi,12(23), 319-334. 
Arkan, K. (2011). Sınıf öğretmenlerinin problem çözme becerisini kazandırmaya yönelik öz-yeterlikleri ile ilköğretim öğrencilerinin problem çözme becerileri arasındaki ilişki (Yayımlanmamış Yüksek Lisans Tezi). Marmara Üniversitesi, İstanbul.

Arslan, A. (2011). Ayrılıp birleşme IV tekniğinin erişiye öz yeterlik inancına ve öz düzenleme becerisine etkisi. Zonguldak Karaelmas Üniversitesi Sosyal Bilimler Dergisi, 7(13), 369-385.

Arslan, A. (2012). Predictive power of the sources of primary school students' self-efficacy beliefs on their self-efficacy beliefs for learning and performance. Educational Sciences: Theory and Practice, 12(3), 1915-1920.

Arslan, A. (2017), Ortaokul Öğrencilerinin Dinleme Kaygıları ve Akademik Özyeterlik İnançlarının Çeşitli Değişkenler Açısından İncelenmesi, International e-Journal of Educational Studies (IEJES), 1(1), 12-31

Aşut, N. (2013). Üstün yetenekli öğrencilerin epistemolojik inançlarının fen öğrenmeye yönelik motivasyon düzeyi ve fen başarısıyla ilişkisi (Yayımlanmamış Yüksek Lisans Tezi). İnönü Üniversitesi, Malatya.

Balyan, M. (2009). ilköğretim 2. kademe ve ortaöğretim kurumlarındaki öğrencilerin beden eğitimi dersine yönelik tutumları, sosyal beceri ve özyeterlik düzeylerinin karşılaştırılması (Yayımlanmamış Doktora Tezi). Ege Üniversitesi, İzmir.

Bandura, A. (1995). Self-efficacy in changing societies. Cambridge: Cambridge Unıversıty Press. doi:10.1017/CBO9780511527692

Baykoç, N. (2012). Özel gereksinimli çocuklar ve özel eğitim. Ankara: Eğiten Kitap.

Berkant, G. H. ve Ekici, G. (2007). Sınıf öğretmeni adaylarının fen öğretiminde öğretmen öz-yeterlik inanç düzeyleri ile zeka türleri arasındaki ilişkinin değerlendirilmesi. Ç.Ü. Sosyal Bilimler Enstitüsü Dergisi, 16(1), 113-132.

Britner, S.L., ve Pajares, F. (2001). Self-efficacy beliefs, motivation, race, and gender in middle school science. Journal of Women and Minorities in Science and Engineering, 7, 271-285.

Büyüköztürk, Ş., Kılıç Çakmak, E., Akgün, Ö.E., Karadeniz, Ş. ve Demirel, F. (2012). Bilimsel araştırma yöntemleri (11. Baskı). Ankara: Pegem Akademi.

Can, A. (2016). SPSS ile bilimsel araşttrma sürecinde nicel veri analizi (4. Baskı.). Ankara: Pegem Akademi.

Chang, C. (1997), Acquisition and development of self efficacy through cooperative learning (Unpublished doctoral dissertation). The University of Texas, Texas.

Çağırgan Gülten, D. ve Soytürk, İ. (2013). İlköğretim 6. sınıf öğrencilerinin geometri öz-yeterliklerinin akademik başarı not ortalamaları ile ilişkisi. Mehmet Akif Ersoy Üniversitesi Eğitim Fakültesi Dergisi, 13(25), 55 - 70.

Çaycı, B. (2013). Illköğretim öğrencilerinin fen ve teknoloji dersi öz-yeterlik inançları ile kavram başarıları arasındaki ilişki. Ahi Evran Üniversitesi Kırşehir Eğitim Fakültesi Dergisi, 14(2), 305-324.

Çetin, B. (2007). Yeni Illköğretim Programı Uygulamalarının Ilköğretim 4. Ve 5. Sınıf Öğrencilerinin Çalışma Alışkanlıkları Ile Öz-Yeterliliklerine Etkisi Ve Öğrencilerin Program Hakkındaki Görüşleri. (Yayınlanmamış Doktora Tezi). Marmara Üniversitesi Eğitim Bilimleri Enstitüsü, İstanbul.

Denizoğlu, P. (2008). Fen bilgisi öğretmen adaylarının fen bilgisi öğretimi öz-yeterlik inanç düzeyleri, öğrenme stilleri ve fen bilgisi öğretimine yönelik tutumları arasındaki ilişkinin değerlendirilmesi. (Yayımlanmamış Yüksek Lisans Tezi). Çukurova Üniversitesi, Adana.

Eccles, J., Wigfield, A., Harold, R. D. ve Blumenfeld, P. (1993). Age and gender differences in children's self- and task perceptions during elementary school. Child Development, 64, 830-847.

Ekici, G. (2008). Sınıf yönetimi dersinin öğretmen adaylarının öğretmen öz-yeterlik algı düzeyine etkisi. Hacettepe Üniversitesi Eğitim Fakültesi Dergisi, 35, 98-110.

Ekinci, E. (2011). Ortaöğretim öğrencilerinin akademik özyeterlik düzeyleri ve akademik erteleme davranışlarının öğrenilmiş çaresizlik düzeylerini yordama gücü. (Yayımlanmamış Yüksek Lisans Tezi). Gazi Osman Paşa Üniversitesi Sosyal Bilimler Enstitüsü, Tokat.

Ekinci Vural, D. ve Hamurcu, H. (2008). Okul öncesi öğretmen adaylarının fen öğretimi dersine yönelik öz-yeterlik inançları ve görüşleri. Illköğretim Online, 7(2), 456-467.

Ercan, S (2007), Sınıf öğretmenlerinin bilimsel süreç beceri düzeyleri ile fen bilgisi öz-yeterlik düzeylerinin karşılaştırılması (Uşak ili örneği). (Yayımlanmamış Yüksek Lisans Tezi). Afyon Kocatepe Üniversitesi, Afyon.

Ferla, J., Valcke, M. ve Cai, Y. (2009). Academic self-efficacy and academic self-concept: Reconsidering structural relationships. Learning and Individual Differences, 19, 499-505. doi:10.1016/i.lindif.2009.05.004

Feyzioğlu, E.Y., Feyzioğlu, B. ve Küçükçıngı, A. (2014). Fen bilgisi öğretmen adaylarının fen öğretimine yönelik zihinsel modelleri, öz yeterlik inançları ve öğrenme yaklaşımları. Ondokuz Mayıs Üniversitesi Eğitim Fakültesi Dergisi, 33(2), 404-423.

Green, S.B. ve Salkind, N.J. (2005). Using SPSS for windows and macintosh: Analyzing and understanding data (4th Edition). New Jersey. Pearson

Güçin, G. ve Oruç, Ş. (2015). Türkiye'de üstün yetenekliler ve üstün zekâlılar alanında yapılmış akademik çalışmaların çeşitli değişkenler açısından değerlendirilmesi. Adıyaman Üniversitesi Eğitim Bilimleri Dergisi, 5(2), 113-115. doi:10.17984/adyuebd.05095

Güvercin, Ö., Tekkaya, C. ve Sungur S. (2010), Öğrencilerin Fen Öğrenimine Yönelik Motivasyonlarının İncelenmesi: Karşılaştırmalı Bir Çalışma, Hacettepe Üniversitesi Eğitim Fakültesi Dergisi (H. U. Journal of Education) 39, 233-243

Hall, J.M. ve Ponton, M.K. (2005). Mathematics self-efficacy of college freshman. Journal of Developmental Education, 28(3), 26-32. 
Hampton, N.Z. ve Mason, E. (2003). Learning disabilities, gender, sources of efficacy, self-efficacy beliefs, and academic achievement in high school students. Journal of School Psychology, 41, 101-112. doi:10.1016/S0022-4405(03)00028-1

Hazır Bıkmaz, F. (2002). Fen öğretiminde öz-yeterlik inancı ölçeği. Eğitim Bilimleri ve Uygulama Dergisi, 1(2), $197-210$.

Hızlıok, A. (2012). Illköğretim birinci kademe 4. sınıf fen ve teknoloji dersinde uygulanan bilimsel süreç becerileri temelli etkinliklerin öğrencilerin fen ve teknoloji özyeterliklerine ve akademik başarılarına etkisi (Yayımlanmamış Yüksek Lisans Tezi). Niğde Üniversitesi, Niğde.

İsrael, E. (2007). Özdüzenleme eğitimi, fen başarısı ve özyeterlilik (Yayımlanmamış Doktora Tezi). Dokuz Eylül Üniversitesi, İzmir.

Junge, M.E. ve Dretzke, B. J. (1995). Mathematical self-efficacy gender differences in gifted/talented adolescents. Gifted Child Quarterly, 39(1), 22-26. doi:10.1177/001698629503900104

Kahyaoğlu, M. ve Pesen, A. (2013). Üstün yetenekli öğrencilerin fen ve teknolojiye yönelik tutumları, öğrenme ve motivasyon stilleri arasındaki ilişki. Türk Üstün Zekâ ve Eğitim Dergisi, 3(1), 38-49.

Kahyaoğlu, M. ve Yangın, S. (2007). İlköğretim öğretmen adaylarının mesleki özyeterliklerine ilişkin görüşleri. Kastamonu Eğitim Dergisi, 15(1), 73-84.

Kanlı, E. (2011). Üstün zekâlı ve normal ergenlerin mükemmeliyetçilik, depresyon ve kaygı düzeyleri arasındaki ilişkilerin incelenmesi. Marmara Üniversitesi Atatürk Eğitim Fakültesi Eğitim Bilimleri Dergisi, 33, 103-121.

Karaaslan, G. ve Sungur, S. (2011). Elementary students' self-efficacy beliefs in science: Role of grade level, gender, and socio-economic status. Science Education International, 22(1), 72-79.

Karaca, M., Bektaş, O. ve Saraçoğlu, S. (2016). Fen bilimleri dersine yönelik özyeterlik ölçeği geliştirme: Geçerlik ve güvenirlik çaIışması. III. International Eurasian Educational Research Congress, Sıtkı Koçman Üniversitesi, Muğla.

Karahan, Ş. ve Uyanık Balat, G. (2011). Özel eğitim okullarında çalışan eğitimcilerin öz-yeterlik algılarının ve tükenmişlik düzeylerinin incelenmesi. Pamukkale Üniversitesi Eğitim Fakültesi Dergisi, 29, 1-14.

Kaya, F., Kanık, P. ve Alkın, S. (2016). Üstün zekalı ve yetenekli öğrencilerin duygusal zeka ve iletişim becerileri düzeylerinin karşılaştirılması. International Online Journal of Educational Sciences, 8 (1), 229-244.

Kıran, D. (2010). Illköğretim öğrencilerinin fen ve teknoloji dersine karşı özyeterlik inançlarının kaynakları ve sonuçları üzerine bir çalışma (Yayımlanmamış Yüksek Lisans Tezi), Ortadoğu Teknik Üniversitesi, Ankara.

Koç, C. ve Arslan, A. (2017). Ortaokul Öğrencilerinin Akademik Öz Yeterlik Algıları ve Okuma Stratejileri Bilişüstü Farkındalıkları. Yüzüncü Yıl Üniversitesi Eğitim Fakültesi Dergisi, 14(1), 745-778. doi: http://dx.doi.org/10.23891/efdyyu.2017.29

Kotaman, H. (2008). Özyeterlilik inancı ve öğrenme performansının geliştirilmesine ilişkin yazın taraması. Uludağ Üniversitesi Eğitim Fakültesi Dergisi, XXI(1), 111-113.

Locke, E.A. ve Latham, G.P. (1990). A theory of goal setting \& task performance. London: International (UK) Limited.

Netz, Y. ve Raviv, S. (2004). Age differences in motivational orientation toward physical activity: an application of social- cognitive theory. The Journal of psychology, 138(1), 35-48

Özdemir, N. (2014). Üstün yetenekli öğrencilerin fen ve teknoloji dersine yönelik tutumlarının incelenmesi (Yayımlanmamış Yüksek Lisans Tezi). Muş Alparslan Üniversitesi, Muş.

Özenç, M. ve Gül Özenç, E. (2012). Türkiye’de üstün yetenekli öğrencilerle ilgili yapılan lisansüstü eğitim tezlerinin çok boyutlu olarak incelenmesi. (Yayımlanmamış Yüksek Lisans Tezi). Niğde Üniversitesi, Niğde.

Özkan,Ö., Tekkaya, C. ve Çakıroğlu, J. (2002). Fen bilgisi aday öğretmenlerin fen kavramlarını anlama düzeyleri, fen öğretimine yönelik tutum ve öz yeterlik inançları. V. Fen ve Matematik Kongresi, Ankara.

Pajares, F. ve Miller, M.D. (1994). Role of self-efficacy and self-concept beliefs in mathematical problem solving: A path analysis. Journal of Educational Psychology, 86(2), 193-203. doi:10.1037/0022-0663.86.2.193

Pajares, F. (1996). Self-efficacy bliefs in academic settings. Review of Educational Research, 66(4), 543-578. doi:10.3102/00346543066004543

Pintrich, P.R. (1999). The role of motivation in promoting and sustaining self-regulated learning. International Journal of Educational Research, 31, 459-470. doi:10.1016/S0883-0355(99)00015-4

Sakız, G. ( 2013). Başarıda Anahtar Kelime: Öz-yeterlik, Uludağ Üniversitesi Eğitim Fakültesi Dergisi 26(1), 185-209

Saracaloğlu, A.S. ve Yenice, N. (2009). Fen bilgisi ve sınıf öğretmenlerinin öz-yeterlik inançlarının bazı değişkenler açısından incelenmesi. Eğitimde Kuram ve Uygulama, 5(2), 244-260.

Say, M. (2005). Fen bilgisi öğretmenlerinin öz-yeterlilik inanışları. (Yayınlanmamış Yüksek Lisans Tezi). Marmara Üniversitesi Eğitim Bilimleri Enstitüsü, İstanbul.

Say, F.S. (2016). Yedinci sınıf fen bilimleri dersine yönelik tasarlanan bilgisayar oyununun öğrencilerin fene yönelik özyeterliklerine, motivasyonlarına ve saldırganlıklarına etkisi (Yayınlanmamış Doktora Tezi). Pamukkale Üniversitesi, Denizli.

Sinan, O., Şardağ, M., Salifoğlu, A., Çakır, C. ve Karabacak, Ü. (2014). Investigation of primary school students' science attitudes and self-efficacy. Necatibey Eğitim Fakültesi Elektronik Fen ve Matematik Eğitimi Dergisi, 8(1), 68-100. 
Şahin Taşkın, Ç. ve Hacıömeroğlu, G. (2010). Öğretmen özyeterlik inanç ölçeğinin Türkçeye uyarlanması ve sınıf öğretmeni adaylarının özyeterlik inançları. Dokuz Eylül Üniversitesi Buca Eğitim Fakültesi Dergisi, 27, 63-75.

Uçak, E. ve Bağ, H. (2012). Elementary school pupils' self efficacy towards science and technology lesson. Journal of Baltic Science Education, 11(3), 203-215.

Ural, A., Umay, A. ve Argün, Z., (2008). Öğrenci takımları başarı bölümleri tekniği temelli eğitimin matematikte akademik başarı ve özyeterliliğe etkisi. Hacettepe Üniversitesi Eğitim Fakültesi Dergisi, 35, 307-318.

Usher, E. L. ve Pajares, F. (2006). Sources of academic and self-regulatory efficacy beliefs of entering middle school students. Comtemporary Educational Psychology, 31, 125-141.

Ülger, B.B., Uçar, S. ve Özgür, İ. (2014). İdareci, öğretmen ve öğrencilerin bakış açısından bilim sanat merkezlerinde uygulanan fen eğitimi programları. Ilköğretim Online, 13(3), 1098-1121.

Tuğran, Z. (2015). İşbirlikli öğrenmenin lise öğrencilerinin matematik özyeterlik algısı ve başarısı üzerindeki etkileri (Yayımlanmamış Yüksek Lisans Tezi). Çanakkale 18 Mart Üniversitesi, Çanakkale.

Yabaş, D. (2008). Farklılaştırılmış öğretim tasarımının öğrencilerin özyeterlik algıları, bilişüstü becerileri ve akademik başarılarına etkisinin incelenmesi (Yayımlanmamış Yüksek Lisans Tezi). Yıldız Teknik Üniversitesi, İstanbul.

Yağbasan, R. ve Gülçiçek, Ç. (2003). Fen öğretiminde kavram yanılgılarının karakteristiklerinin tanımlanması. Pamukkale Üniversitesi Eğitim Fakültesi Dergisi, 1(13), 102-120.

Yaman, S. (2016). Ortaokul öğrencileri için fen öğrenmeye yönelik öz-yeterlik inanç ölçeği uyarlaması: Geçerlik ve güvenirlik çalışması. İnönü Üniversitesi Eğitim Fakültesi Dergisi, 17(2), 123-140.

Yaman, S., Cansüngü Koray, Ö. ve Altunçekiç, A. (2004). Fen bilgisi öğretmen adaylarının öz-yeterlik inanç düzeylerinin incelenmesi üzerine bir araştırma. Türk Eğitim Bilimleri Dergisi, 2(3), 355-366.

Yenilmez, K. ve Kakmacı, Ö. (2008). İlköğretim matematik öğretmenliği bölümü öğrencilerinin öz yeterlilik inanç düzeyleri. Eskişehir Osmangazi Üniversitesi Sosyal Bilimler Dergisi, 9(2), 1-21.

Yenilmez, K. ve Uygan, C. (2010). Yaratıcı drama yönteminin ilköğretim 7. sınıf öğrencilerinin geometriye yönelik öz-yeterlik inançlarına etkisi. Kastamonu Eğitim Dergisi, 18(3), 931-942.

Yılmaz, E., Yiğit, R. ve Kaşarcı, İ. (2012). İlköğretim öğrencilerinin özyeterlilik düzeylerinin akademik başarı ve bazı değişkinler açısından incelenmesi. Mehmet Akif Ersoy Üniversitesi Eğitim Fakültesi Dergisi, 12(23), 371 - 388.

Yurt, E. (2014). The Predictive power of self-efficacy sources for mathematics achievement. Education and Science, 39(176), 159169. doi:10.15390/EB.2014.3443

Zimmerman, B.J. (1995). Self-efficacy and educational development. In A.Bandura (Ed.), Self-efficacy in changing societies (s.202231). New York: Cambridge Univercity Press. doi:10.1017/CBO9780511527692.009

Zimmerman, B.J., Bandura, A. ve Martinez-Pons, M. (1992). Self-motivation for academic attainment: The role of self-efficacy bliefs and personal goal setting. American Educational Research Journal, 29(3), 663-676. doi:10.3102/00028312029003663 